\title{
Cyclonic cold-core eddy in the eastern North Atlantic. I. Physical description
}

\author{
Ekkehard Mittelstaedt \\ Deutsches Hydrographisches Institut, Postfach 220, 2000 Hamburg 4, Federal Republic of Germany
}

\begin{abstract}
Many rings or eddies have been described in the western North Atlantic, but only a very few in the eastern part. Here we report on a cyclonic cold-core eddy which cut off from a Polar Front meander in the vicinity of $48.5^{\circ} \mathrm{N}, 22^{\circ} \mathrm{W}$ in May 1985 . The eddy extended down to at least $2500 \mathrm{~m}$ depth. Its diameter was of the order of $100 \mathrm{~km}$ in the upper layer and $200 \mathrm{~km}$ at greater depths. Its surface signal was weak in temperature but strong in salinity. Geostrophic circulation around the eddy reached speeds of 30 to $40 \mathrm{~cm} \mathrm{~s}^{-1}$, and net displacement speed was about $3 \mathrm{~cm} \mathrm{~s}^{-1}$ northeastwards. The ambient water mass consisted mainly of North Atlantic Central Water (NACW) from below the surface layer down to $800 \mathrm{~m}$ depth. The interior water (core) of the eddy had an interleaving vertical structure consisting of: a mixture of water types within the upper layer above $200 \mathrm{~m}$ depth; NACW between 200 and $400 \mathrm{~m}$ depth; predominantly admixtures of Subarctic Intermediate Water (SAIW) between 400 and $500 \mathrm{~m}$ depth. Beneath the SAIW and NACW the eddy showed traces of Mediterranean Water in the layer from 600 to $1000 \mathrm{~m}$ and deep water with admixtures of Labrador Sea Water at depths between 1400 and $2000 \mathrm{~m}$.
\end{abstract}

\section{INTRODUCTION}

Mesoscale eddies represent a special class of ocean turbulence. Most eddies are in quasigeostrophic balance and have time scales of weeks to months. Some of them, for instance Gulf Stream rings, have a lifetime from a month to more than a year (see reviews in Robinson 1983). An example of such an oceanic ring is described in this and the following 2 articles (Beckmann et al. 1987, Lochte \& Pfannkuche 1987). Although a turbulent element, the geostrophy and the long lifetime allow such an eddy to be considered as a systematic and orderly phenomenon.

Eddies are formed in regions with strong current shear. This happens, for example, along the flanks of large jets such as the Gulf Stream. In the North Atlantic most rings have been observed in the western half of this ocean, in the vicinity of the Gulf Stream and its extensions. They are initially associated with waveor meander-type disturbances which eventually pinch off from the main stream in form of rings or eddies. They transport momentum, heat, physical and chemical water properties and small organisms over long distances from their origin. Sometimes the interior waters of rings exhibit ecosystems distinct from ambient waters (Angel \& Fasham 1983). A basic oceanographic motivation for the study of mesoscale eddies is the estimation of their rôle in large-scale mixing in the ocean.

One of the best previous analyses of an eddy in the eastern North Atlantic comes from the French 'Tourbillon' experiment (Le Groupe Tourbillon 1983, Arhan \& de Verdière 1985, Harvey \& Glynn 1985). These workers described an anticyclonic warm-core eddy in the vicinity of $47^{\circ} \mathrm{N}$ and $15^{\circ} \mathrm{W}$, that moved slowly westwards with a net speed of about $2 \mathrm{~cm} \mathrm{~s}^{-1}$. Maximum rotational speeds of $30 \mathrm{~cm} \mathrm{~s}^{-1}$ were observed at depths around $500 \mathrm{~m}$ some $20 \mathrm{~km}$ from the centre. Rotation was evident from the surface down to $4000 \mathrm{~m}$ depth. The upper core of the eddy consisted of an accumulation of Northeast Atlantic Central Water indicating that this eddy had been formed in the eastern North Atlantic (Harvey \& Glynn 1985).

\section{METHODS AND OBSERVATIONS}

In the framework of the 2 regional monitoring programmes NOAMP * and BIOTRANS * , oceanographi-

\footnotetext{
- Nord-Ost-Atlantisches Monitoring-Programm

- BIOlogischer TRANSport
} 


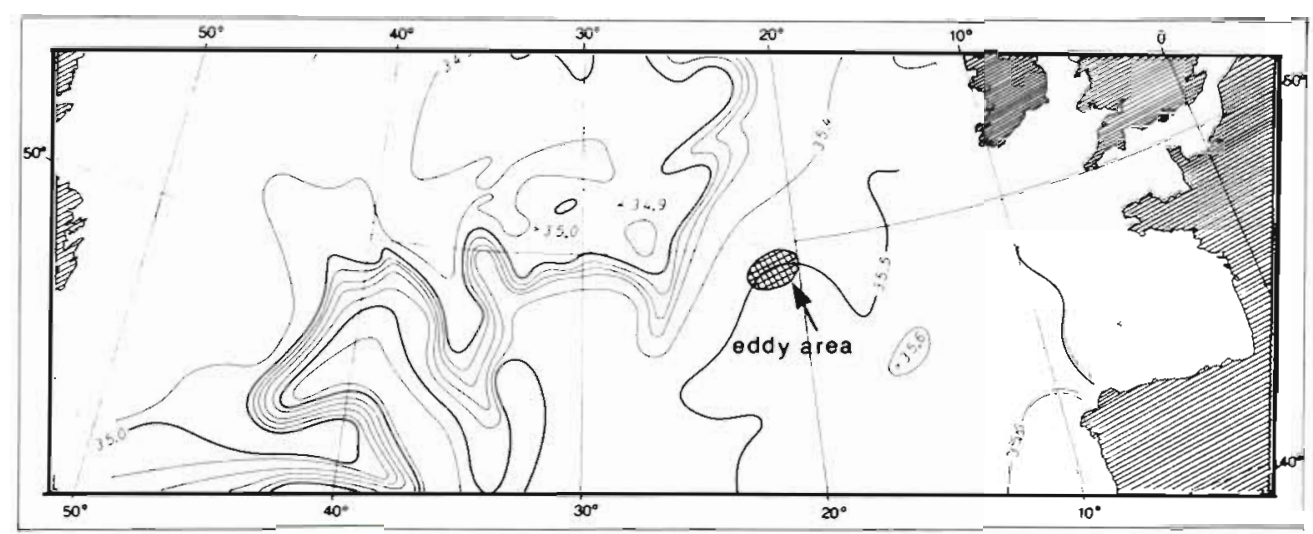

Fig. 1. Salinity distribution in winter 1958 at a depth of $500 \mathrm{~m}$ (from Dietrich 1969) and the geographical location of the observed eddy

cal and biological investigations were carried out from the RV Meteor (cruise No. 70 ) in the eastern North Atlantic around $47^{\circ} 30^{\prime} \mathrm{N}$ and $20^{\circ} \mathrm{W}$ from February to May 1985. During field work, a remarkable hydrographic structure was encountered that turned out to be a huge current meander. The interior of the meander consisted of cool and relatively low salinity water. The spatial pattern and temperature/salinity relation of the core suggested that the meander originated from the Polar Front (zone of strong horizontal gradients; Fig. 1).

When first surveyed from 22 to $26 \mathrm{Apr} 1985$, the meander extended nearly $300 \mathrm{~km}$ towards the southeast and was about $40 \mathrm{~km}$ wide. Strongest horizontal gradients occurred at depths of ca $475 \mathrm{~m}$. The vertical isotherm excursion was about $400 \mathrm{~m}$ in the 8 to $11^{\circ} \mathrm{C}$ range. Surface temperature $\mathrm{T}$ of the core water $\left(10.5^{\circ} \mathrm{C}\right.$ $<\mathrm{T}<11^{\circ} \mathrm{C}$ ) was about $1.5 \mathrm{C}^{\circ}$ below ambient water. Conductivity, temperature and depth-data (CTD-data) suggested the meander persisted to at least $2500 \mathrm{~m}$. Geostrophic calculations yielded a cyclonic rotation around the meander with maximum speeds above $700 \mathrm{~m}$ depth from $10 \mathrm{~cm} \mathrm{~s}^{-1}$ below to $36 \mathrm{~cm} \mathrm{~s}^{-1}$ at the surface (Kupferman et al. 1986).

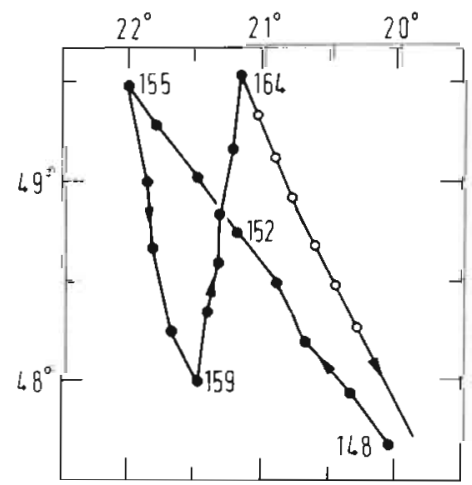

Fig. 2. Track and stations during the eddy survey (17 to 20 May 1985). ( $\bullet$ CTD locations; (c) XBT locations
Using an Ocean Descriptive Predictive System (Marietta \& Robinson 1986) for shipboard ocean forecasting, the short-term development of the meander was predicted. The forecast suggested that the meander would quickly cut off, forming a cyclonic eddy with a closed rotation centre moving slowly northeastwards over the following $3 \mathrm{wk}$. On the basis of this information the meander was relocated about $3 \mathrm{wk}(17$ to 20 May) after the first survey. A survey was started at Stn 148 (Fig. 2) along a section towards the northwest. As ship-time was limited, the Neil Brown CTD was lowered only to $1500 \mathrm{~m}$. At the edge of the cold core we observed a school of whales. Within the eddy centre, we noticed the characteristic odour of plankton. Using the CTD profiles to obtain a rough idea about the extension of the eddy, stations were selected for biological sampling along the SW-NE section (Stn 159 to 164) to study the eddy's ecosystem (Beckmann et al. 1987, Lochte \& Pfannkuche 1987).

The domelike structure of the stratification associated with the eddy is shown in Fig. 3. The temperature sections correspond almost exactly to those across the meander in April, 3 wk earlier.

During the first survey, most eddy data came from Expendable Bathythermograph (XBT) profiles down to $900 \mathrm{~m}$ depth. The CTD stations were too few to resolve the meander's small-scale structure apparent in the XBT temperature sections. However, since the CTDprofiles during the first survey covered the whole water column, the data did reveal the basic temperature/ salinity properties within and outside the eddy as well as the approximate depth to which the eddy was still perceivable (about $2500 \mathrm{~m}$ ). The second survey was carried out mostly using a CTD-probe to $1500 \mathrm{~m}$. Only the easternmost section, due to time limitations, consisted of 6 XBT stations at distances of $20 \mathrm{n}$ miles.

In the surface layer, above $50 \mathrm{~m}$, temperature manifestations of the eddy were weak (Fig. 3a). Surface 

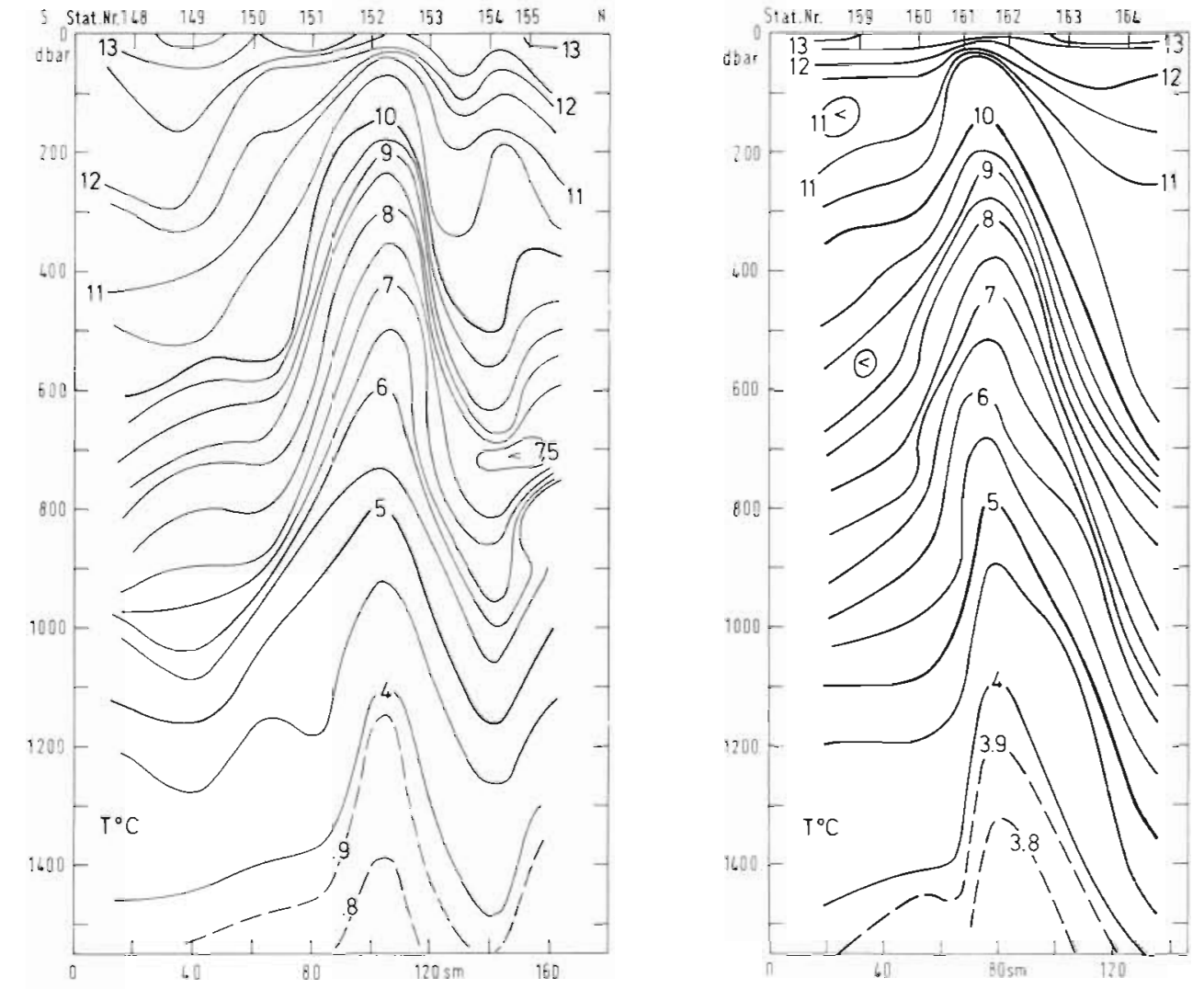

Fig. 3 (a, b). Cross-sections of the eddy. See Fig. 2 for locations of tracks. (a) Temperature. (b) Salinity
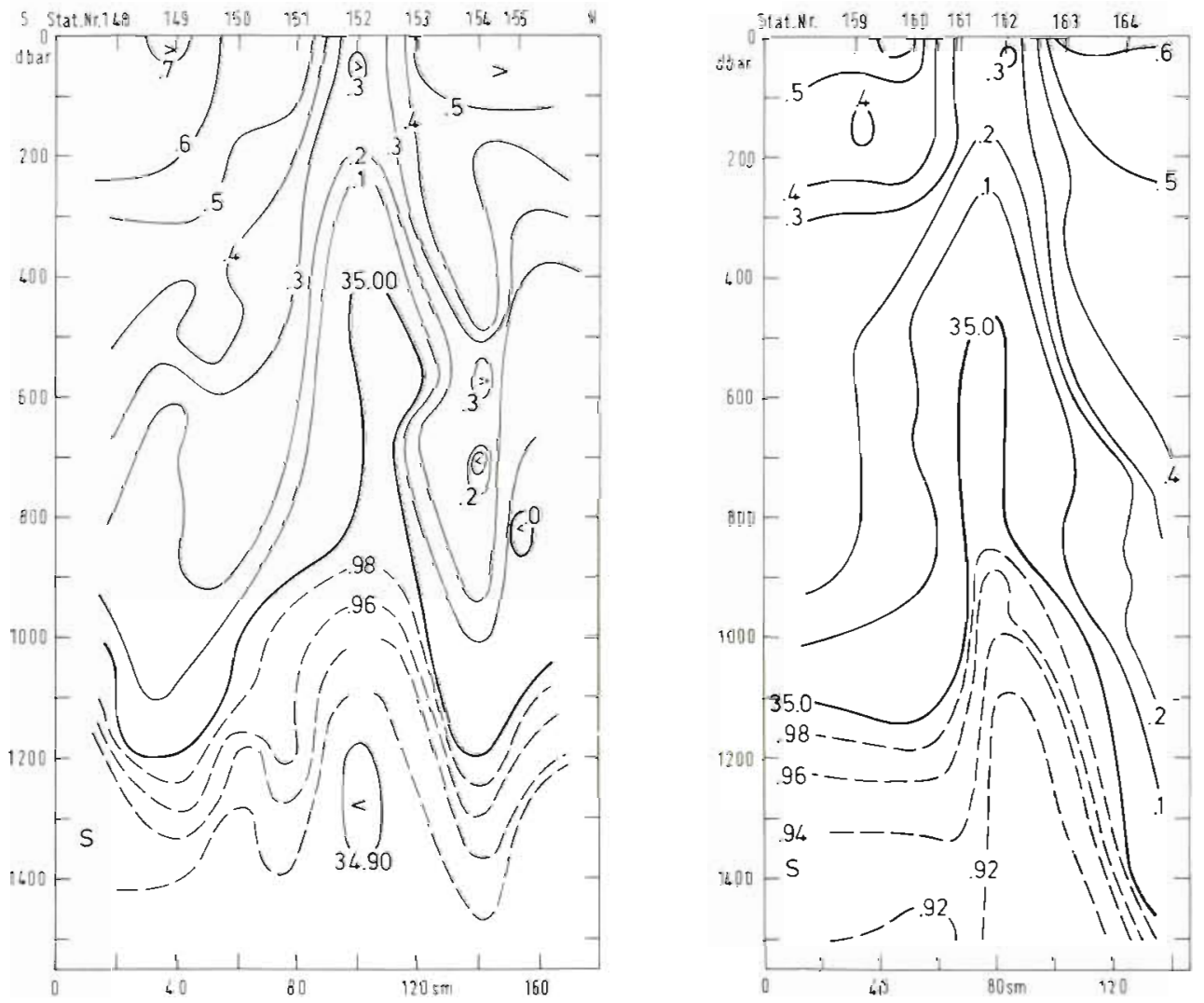

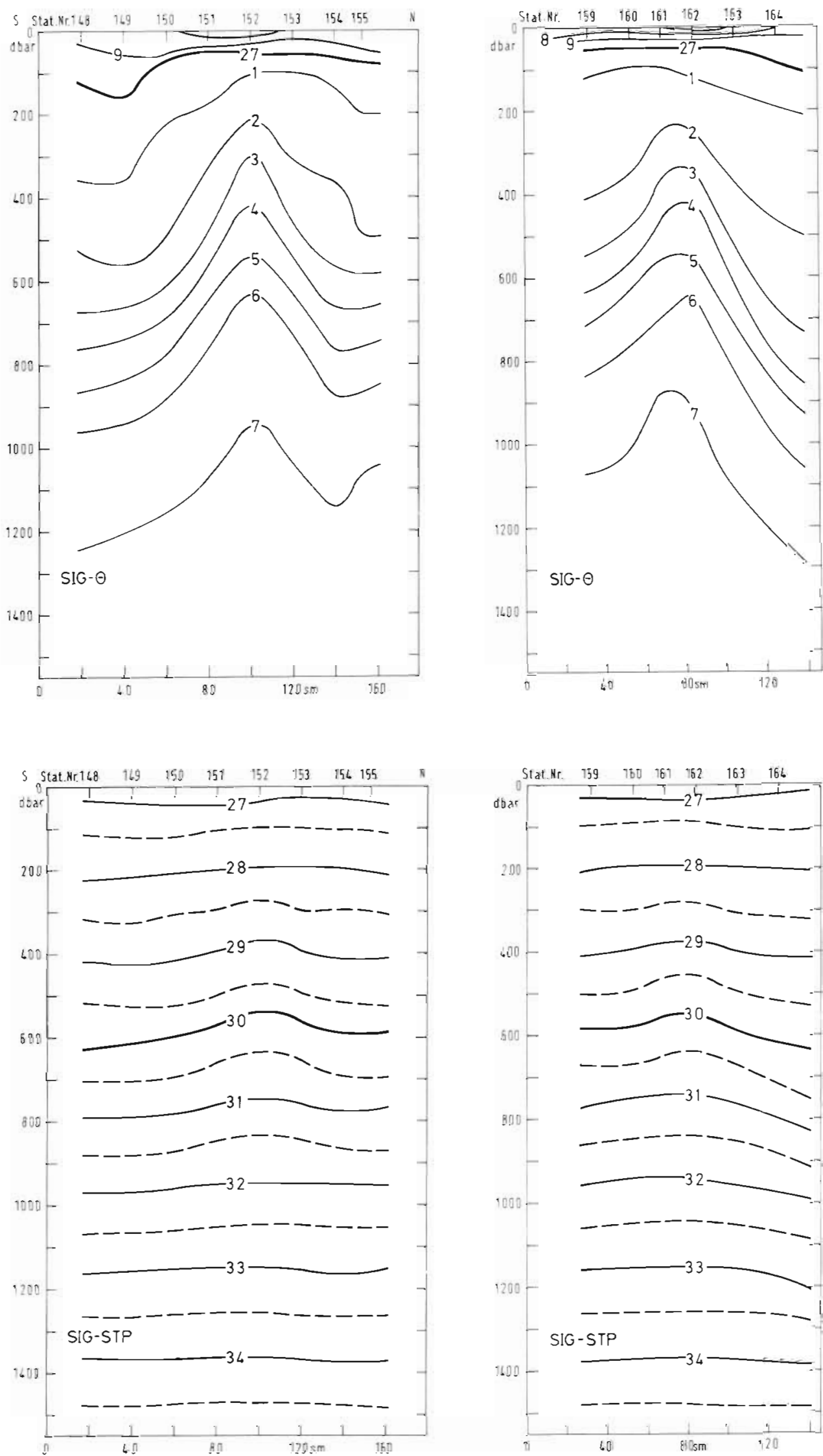

Fig. 3 (c). Potential density (above) and in situ density (below). Potential density (SIG- $\theta$ ) excludes and in situ density (SIG-STP) includes the water pressure upon the density. Numbers at the density lines (isopycnals) represent 1.0268 to 1.0277 $\mathrm{g} \mathrm{cm}^{-3}$ (SIG- $-\theta$ ) and 1.027 to $1.035 \mathrm{~g} \mathrm{~cm}^{-3}$ (SIG-STP). (The first 2 digits are omitted) 


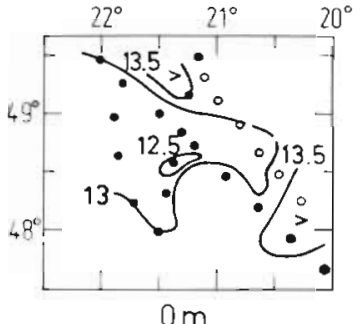

$\mathrm{T}^{\circ} \mathrm{C}$

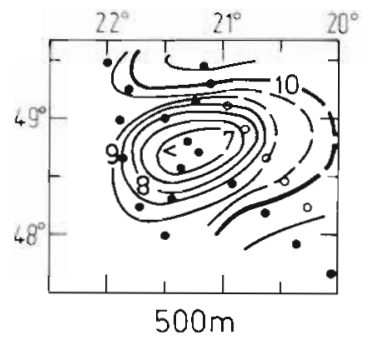

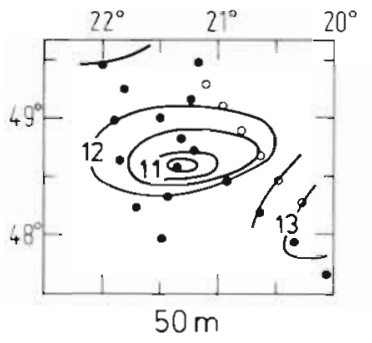

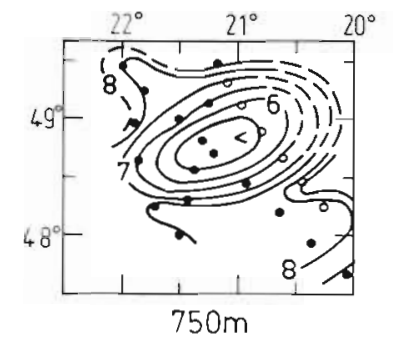

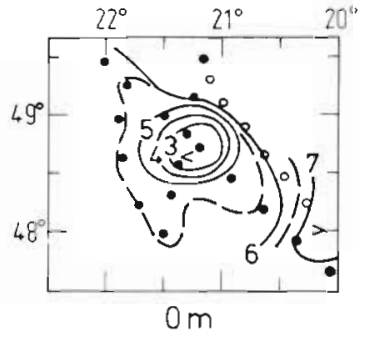

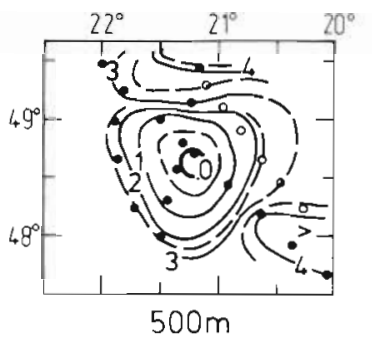

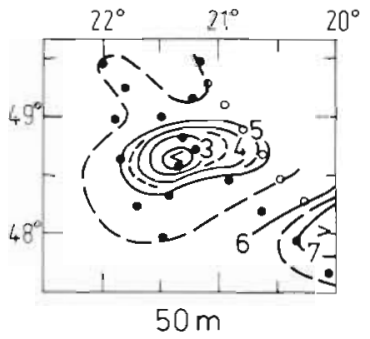

S

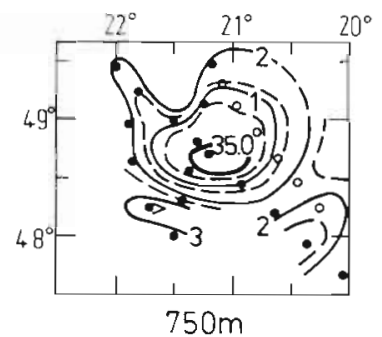

Fig. 4. Horizontal sections at depths of 0,50,500 and $750 \mathrm{~m}$. Left: temperature. Broken isotherms are uncertain due to missing data outside the survey grid. Right: salinity. Numbers represent $0.1 \%$ for $>35.0 \%$ (e.g. $5 \equiv 35.5 \%$ ). Broken isohalines denote $0.05 \%$ inside and uncertain distribution outside the survey grid. (•) CTD locations; ( $(0)$ XBT locations (see text)

temperature of the eddy core and the ambient water rose by 1 to $2 \mathrm{C}^{\circ}$ during the $3 \mathrm{wk}$ interval between the 2 surveys. The overall temperature gradient at the surface between the core water and ambient water was relatively weak in May. We assume that the overall temperature increase between April and May was mainly due to seasonal warming. Because of the weak surface temperature gradient associated with the eddy, it was not possible to find satisfactory evidence of this feature in remote sensing satellite images.

The salinity sections (Fig. 3b), however, show relatively sharp gradients with differences in salinity at the surface of 0.3 to $0.4 \%$ between core water and ambient water. Within the core the water was almost homohaline from the surface down to $200 \mathrm{~m}$. The vertical isohalines intersect the near-surface isotherms which run more or less horizontally. This observation suggests that mixing between core water and ambient water was weak and supports the idea mentioned above that the surface temperature increase within and around the eddy was caused by seasonal warming.

Because the survey was limited in space and time, we cannot tell whether the eddy was still attached to the Polar Front. However the patterns of temperature and salinity suggest a number of closed lines indicating a clear tendency towards a newly-formed eddy growing from the meander (Fig. 4). Salinity values for the XBT positions were derived from temperature/salinity relations given by the CTD-stations within ( 3 profiles) and outside ( 4 profiles) the eddy. Kupferman et al. (1986) show the temperature distribution of the meander from the first survey during April at $475 \mathrm{~m}$ depth. A comparison of their results with the temperature dis- tribution at $500 \mathrm{~m}$ in May suggests that the 8 and $9{ }^{\circ} \mathrm{C}$ isotherms which defined the stretched tongue of the meander on the first survey were closed about $3 \mathrm{wk}$ later, indicating a cyclonic motion of the eddy. At the same time its cold core had been displaced by about $40 \mathrm{n}$ miles $(75 \mathrm{~km})$ to the northeast (Fig. 5). This corresponds to a displacement speed of about $3 \mathrm{~cm} \mathrm{~s}^{-1}$.

The subsurface horizontal gradients of temperature and salinity, and their maximum values between 400 and $800 \mathrm{~m}$, were about the same in May as in April. This indicates that the energy of rotation had not changed. The density sections (Fig. 3c) point to vigorous cyclonic eddy motions with unchanged maximum speeds above $700 \mathrm{~m}$. For dynamic reasons the cyclonic rotation is coupled with upwelling within the core.

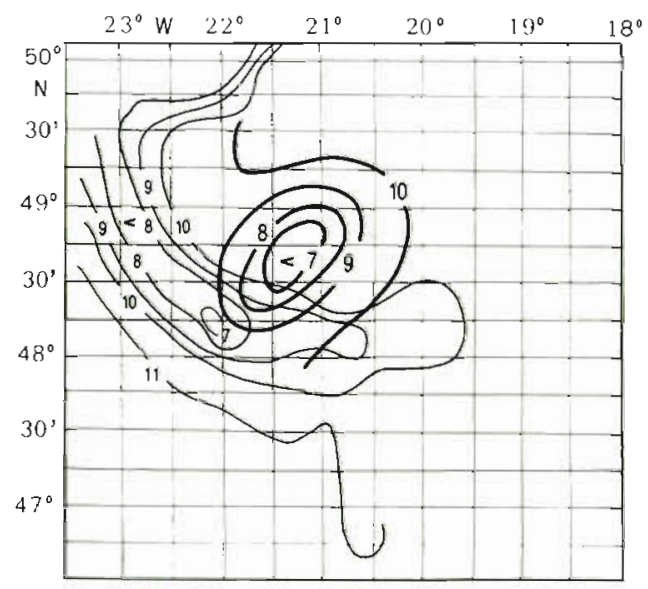

Fig. 5. Eddy formation. Temperature distributions: at depth $475 \mathrm{~m}$ (thin lines) during first survey from 22 to $26 \mathrm{Apr}$ (according to Kupferman et al. 1986); at depth $500 \mathrm{~m}$ (thick lines) during second survey from 17 to 20 May 1985 


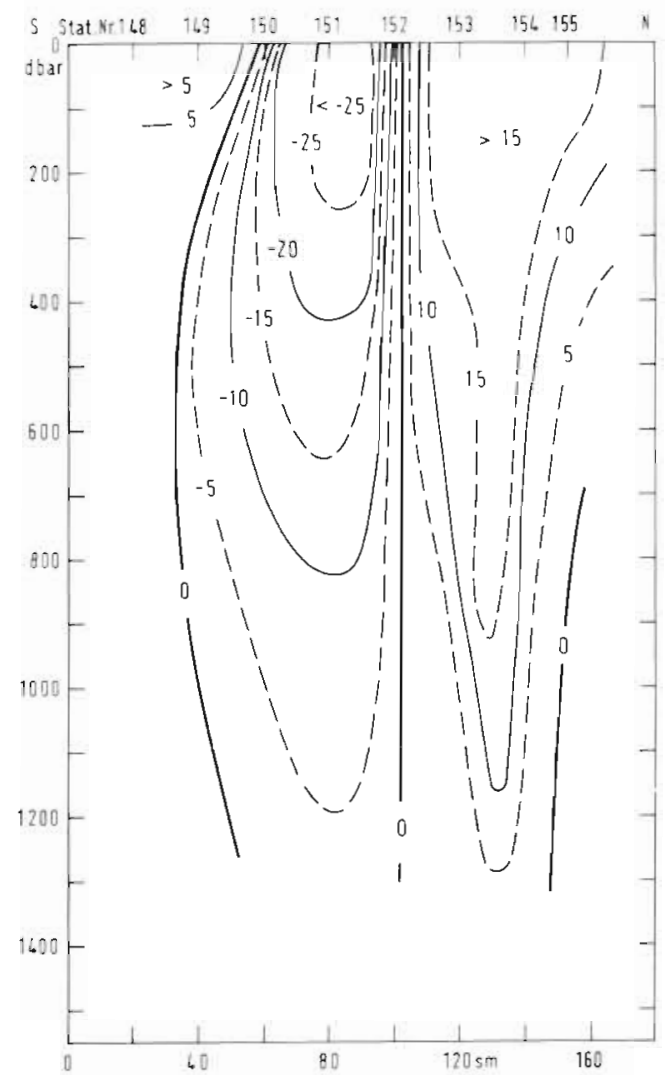

The geostrophic velocities can be derived from the equation for a steady-state circular flow

$$
\frac{\mathrm{v}^{2}}{\mathrm{r}}+\mathrm{fv}=\frac{1}{\rho} \frac{\delta \mathrm{p}}{\delta \mathrm{r}}
$$

where $\mathrm{v}=$ velocity; $\mathrm{r}=$ radius of the eddy; $\mathrm{f}=$ Coriolis parameter; $\rho=$ density of seawater; $p=$ pressure. Since $\frac{v^{2}}{r}<<f v$ it is sufficient, however, to use the simplified equation

$$
\mathrm{fv}=\frac{1}{\rho} \frac{\delta \mathrm{p}}{\delta \mathrm{r}}
$$

for a rectilinear flow. Our geostrophic estimates relative to $1500 \mathrm{~m}$ water depth yield speeds up to $37 \mathrm{~cm} \mathrm{~s}^{-1}$ at a distance of 20 to $30 \mathrm{n}$ miles ( 35 to $55 \mathrm{~km}$ ) from the eddy centre (Fig, 6).

\section{DISCUSSION}

Through the 2 NOAMP surveys, generation of a cyclonic cold-core eddy in the Northeast Atlantic was observed developing from a meander of the Polar Front.

The subsurface water surrounding the eddy, with relatively high temperatures and high salinities, corresponded to North Atlantic Central Water (NACW) for the temperature range from 8 to ca $12^{\circ} \mathrm{C}$ (Fig. 7). The $\mathrm{NACW}$ is a typical subsurface water mass for almost the entire North Atlantic south of the Polar Front and north of the equatorial zone. It is formed by the sinking of surface water due to winter convection and mixing while it spreads with the general subsurface circulation (Sverdrup et al. 1942). In the temperature range 8 to $12^{\circ} \mathrm{C}, \mathrm{NACW}$ is practically identical with the Northeast Atlantic Central Water or the eastern North Atlantic Water defined by Harvey (1982) and Harvey \& Glynn (1985), which forms by wintertime convection in the eastern North Atlantic.

Above $200 \mathrm{~m}$ depth, the eddy core water represented a mixed water type containing admixtures of NACW and Subarctic Intermediate Water (SAIW). SAIW is the dominant water mass within the upper $600 \mathrm{~m}$ depth along the cold side of the Polar Front (Harvey 1982). From Dietrich's Atlas (1969) and Harvey's (1982) water mass classification the temperature (T)/salinity (S) domain of SAIW is defined here by the values: $5^{\circ} \mathrm{C} \leq \mathrm{T}$ $\leq 8^{\circ} \mathrm{C}: 34.85 \% \leq \mathrm{S} \leq 35.00 \%$. Between 200 and $400 \mathrm{~m}$ depth the core water consisted predominantly of NACW and within the layer from 400 to $500 \mathrm{~m}$ the temperature/ salinity properties corresponded almost to those of SAIW This interleaving structure of different water masses likely reflects the vertical layering in the area of origin along the Polar Front when the meander formed. 
Fig. 7. Temperature/salinity diagram of the eddy core (CW) and ambient water (AW). Numbers at the temperature/salinity domains indicate the depth ranges in decametres of the different water masses AW, CW and SAIW (Subarctic Intermediate Water). The range of North Atlantic Central Water (NACW) is represented by 3 broken lines above $8^{\circ} \mathrm{C}$. The median line indicates the mean temperature/salinity characteristic of NACW

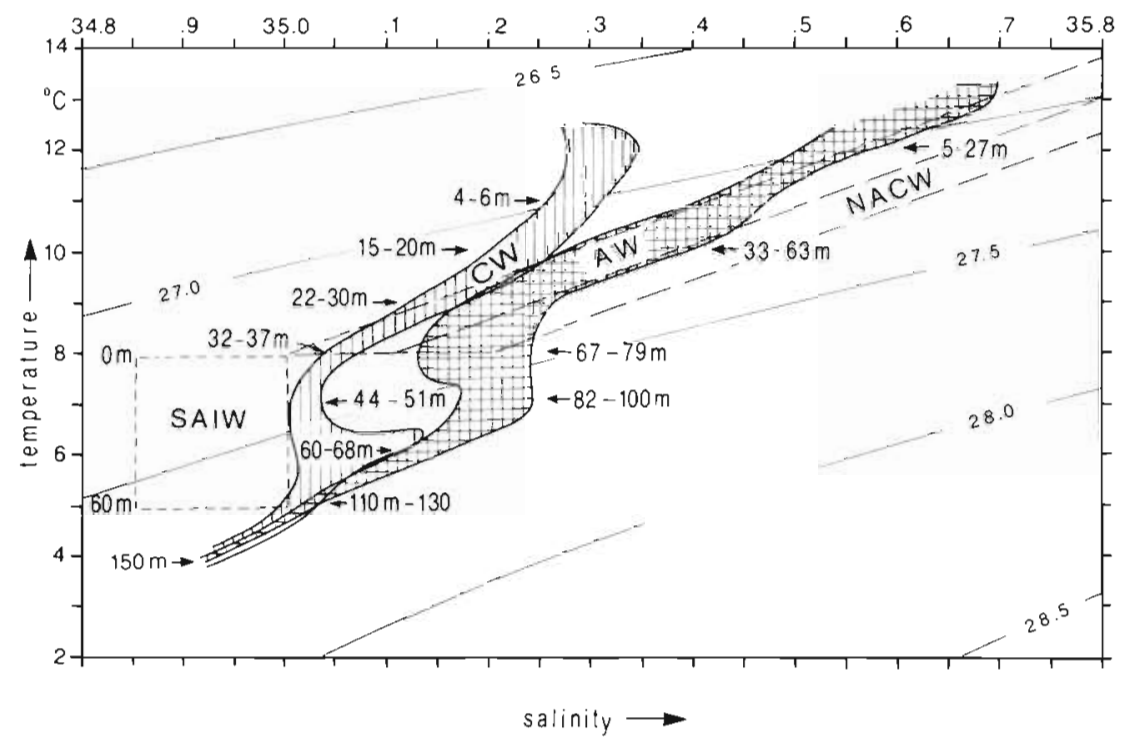

At greater depths the eddy showed traces of Mediterranean Water (salinity maximum) between 600 and $700 \mathrm{~m}$ in its core, and between $800 \mathrm{~m}$ and $1000 \mathrm{~m}$ in the ambient water. These traces were relatively saline admixtures of Mediterranean outflow water, which spread almost over the entire Northeast Atlantic and were entrained by the eddy. Beneath the Mediterranean water, the eddy stirred the deep water with its characteristic admixtures of Labrador Sea Water in the layer from 1400 to $2000 \mathrm{~m}$. This water mass from the North is identifiable by its low salinity and high oxygen concentration at these depths.

According to Dietrich's atlas (1969) the Polar Front runs on average from southwest to northeast in this region and crosses $50^{\circ} \mathrm{N}$ between 25 and $30^{\circ} \mathrm{W}$ at subsurface depths. At $500 \mathrm{~m}$ depth, a level of maximum horizontal gradients of the front, similar temperatures and salinities to the eddy core can be found in this atlas along the front about $300 \mathrm{~km}$ west to northwest of the eddy (Fig. 1 \& 8). This distance coincides with the length of the meander tongue in April and indicates its geographical origin. During the April survey the meander was still completely connected to the Polar Front, which supplied the core with newly mixed frontal water. After pinching off from the meander in May the eddy was disconnected from further water mass renewal.

Satellite images suggest that eddies, meanders and rings (generally denoted as eddies) are common in the ocean. In fact, these images reveal that such phenomena dominate the short-term and mesoscale dynamics of the ocean surface layer. Only remote sensing from space enables marine scientists to recognize these features at the sea surface synoptically on a global scale. The observed patchiness and local variability of small marine organisms in the ocean are partly

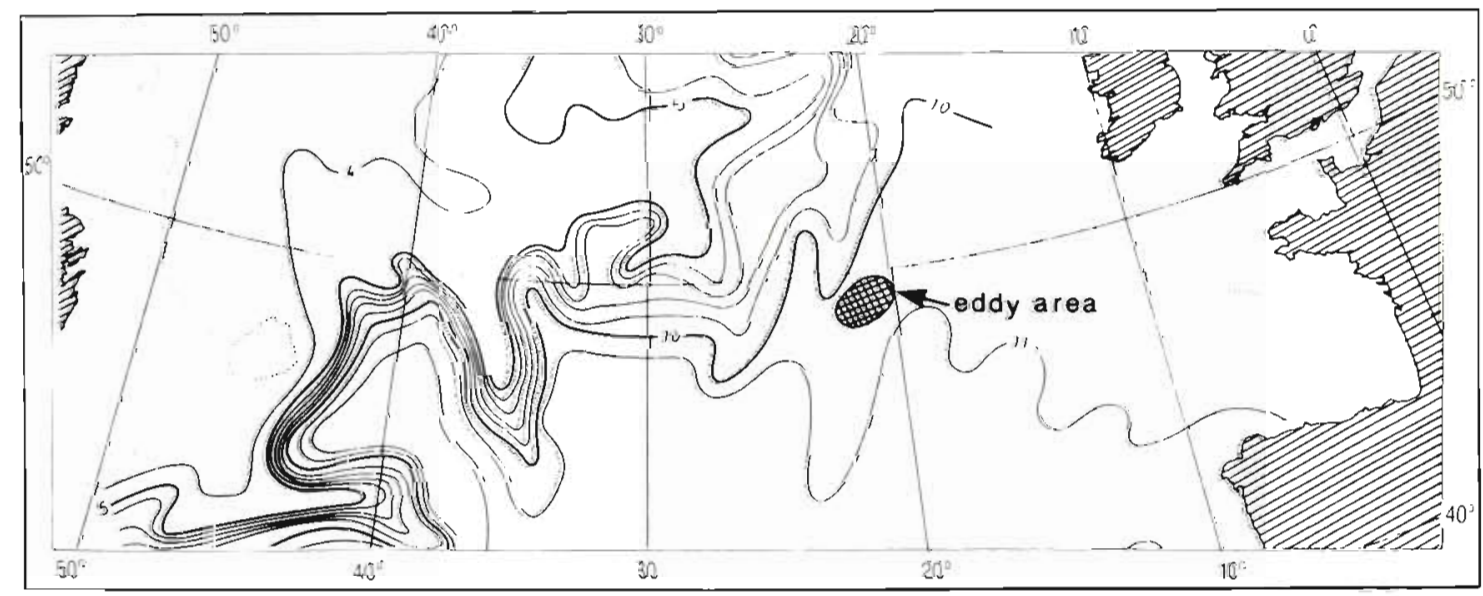

Fig. 8. Temperature distribution in winter 1958 at a depth of $500 \mathrm{~m}$ (from Dietrich 1969) and the geographical location of the observed eddy 
induced by them. Eddies forming at the Polar Front cause water transport across the frontal zone. Thus, they produce a certain permeability of the front with respect to small organisms, which normally dwell only on either side of the Polar Front.

Acknowledgements. This work was supported by the Bundesminister für Forschung und Technologie in the framework of NOAMP. Special thanks are due to Drs M. G. Marietta of Sandia National Laboratories, Albuquerque, and W. F. Simmons, Woods Hole, who read the manuscript and made helpful corrections and suggestions.

\section{LITERATURE CITED}

Angel, M. V., Fasham, M. J. R. (1983). Eddies and biological processes. In: Robinson, A. R. (ed.) Eddies in marine science. Springer-Verlag, New York, p. 492-524

Arhan, M., de Verdière, A. C. (1985). Dynamics of eddy motions in the eastem North Atlantic. J. phys. Oceanogr. 15 (2): 153-170

Beckmann, W., Auras, A., Hemleben, C. (1987). Cyclonic cold- core eddy in the eastern North Atlantic. III. Zooplankton. Mar. Ecol. Prog. Ser. 39: 165-173

Dietrich, G. (1969). Atlas of the hydrography of the northern Atlantic Ocean. International Council for the Exploration of the Sea, Copenhagen

Harvey, J. (1982). $\Theta-S$ relationships and water masses in the eastern North Atlantic. Deep Sea Res. 29: 1021-1033

Harvey, J., Glynn, S. (1985). Water mass structure and transport in the Tourbillon eddy. Deep Sea Res. 32: 675-695

Kupferman, S. L., Becker, G. A., Simmons, W. F., Schauer, U., Marietta, M. G., Nies, H. (1986). An intense cold core eddy in the North East Atlantic. Nature, Lond. 319: 474-477

Le Groupe Tourbillon (1983). The Tourbillon experiment: a study of mesoscale eddy in the eastern North Atlantic. Deep Sea Res. 30: 475-511

Lochte, K., Pfannkuche, O. (1987). Cyclonic cold-core eddy in the eastern North Atlantic. II Nutrients, phytoplankton and bacterioplankton. Mar. Ecol. Prog. Ser. 39: 153-164

Marietta, M. G., Robinson, A. R. (1986). Status and outlook of ocean modelling research dispersion and related applications. SANDIA REPORT, Sand 85-2806, UC-70

Robinson, A. R. (ed.) (1983). Eddies in marine science. Springer-Verlag. New York

Sverdrup, H. U., Johnson, M. W., Fleming, R. H. (1942). The Oceans. Prentice-Hall, New York

This article was submitted to the editor; it was accepted for printing on May 5, 1987 